\title{
PRIESTLY IDENTITY IN THE CZECH LANDS IN 1820-1938 AS A RESEARCH TOPIC. PROJECT EVALUATION
}

\author{
Lukáš Fasora \\ Masaryk University Brno \\ Jiří Hanuš \\ Masaryk University Brno \\ Tomáš W. Pavlíček \\ Masaryk Institute and Archive of the ASCR
}

\begin{abstract}
The paper sums up the results of a project realized by thirteen prominent Czech scholars. The project involved a discussion of priestly identities in the Czech lands at the turn of the $19^{\text {th }}$ and $20^{\text {th }}$ centuries. The outcome of the project is a book entitled Priestly Identity in the Czech Lands (1820-1938), which is now in print. We understand the term identity to mean a form of belonging to human society defined by a person's self-consciousness, i.e. the experience of what an individual thinks or feels. By following the latest research in psychology, social psychology and psycho-history, we perceive identity to be both a personal and social phenomenon. For the requirements of our research we understand identity to be predominantly a historical phenomenon. The project is part of a Central European research on identity that deploys biographical and generational methods. The researched types of priests seem to be particularly suitable for this method as the Czech society is characterized by secularization, separation of the national movement from Catholicism, conflicts between the Czech and German populations, modernist movement and foundation of a national Church in 1920.
\end{abstract}

Key words: identity, priesthood, modern era, secularization, religiosity in the Czech lands.

Over the past twenty years the issue of identity has been a recurring topic in Czech historiography. This can be seen in debates concerning definitions and appropriate methods for understanding this category, and has been the subject of at least three

Addresses for correspondence: fasora@phil.muni.cz; jirh1963@gmail.com; Tomas.Pavlicek1@seznam.cz 
important Czech publications over the past few years. ${ }^{1}$ However, the group of authors involved in the publication of Priestly Identity in the Czech lands $(1820-1938)^{2}$ did not set out to broaden the debate on identity with another serious methodological text, but focused more on the question of which sociological, psychological or philosophical category of identity ties in with the strongly source-based research. ${ }^{3}$ In this sense, our approach is conservative in terms of historians' work, since what is of primary importance to us is capturing such a fluid category as identity in a sufficiently representative way. ${ }^{4}$ Though previous attempts to achieve this were by no means unconvincing, we still saw some shortcomings which we wanted to address: and this was to be achieved using a group of authors who were united enough in terms of their enquiry and methodological approaches to be able to publish their results in a book which met the objective of confirming the usefulness of the category of identity in historical research.

We understand identity to mean a form of belonging in human society defined by a person's self-consciousness, i.e. the experience of what an individual thinks or feels. By following the latest research in psychology, social psychology and psycho-history, we perceive identity to be both a personal phenomenon and a social one. In the first case, identity is interesting as part of an individual's personal self-concept, including the perception of how the person is seen by those around him. In the second case, we are interested in a set of values, signs (particularly symbolic ones) and conditions which create unity between an individual and the group. For the requirements of our research we understand identity to be predominantly a historical phenomenon, which emphasizes the possibility of individual choice or changes in identity. Therefore, we examined priests during adolescence, when identity is significantly influenced by outside factors, in particular the social environment, sometimes even unknowingly. We also reflected on another phase of the priest's life when he was trying to acquire or adapt his identity based on the role assigned to him by those around him, authorities, the expectations of his superiors, fellow brethren or parishioners. As a result of the accelerating changes in society and the pressures

P. Mare k, Identita kněžské generace 20. let 20. století [Priestly Generation Identity of Generation of the twenties of the 20th century], "Církevní dějiny" 2014, Roč. 7, č. 15, pp. 9-30; M. Power, R. K u č e ra, Úvod: Kategorie identity v současné historiografii [Introduction: The Category of Identity in Contemporary Historiography] [in:] R. Kučer a et al., Identity v českých zemich 19. a 20. století: Hledani a promenny [Identities in the Czech Lands in the $19^{\text {th }}$ and $20^{\text {th }}$ Centuries: Searches and Transformations], Prague 2012, pp. 9-23; J. H a n u š, P. H u sák, Kněžská identita ve 20. století [Priestly Identity in the $20^{\text {th }}$ century] [in:] J. H a nuš et al., ,Služebníci neužitečni”. Kněžská identita v českých zemích ve 20. stoleti ["Useless Servants". Priestly Identity in the Czech Lands in the 20th Century], Brno 2015, pp. 5-48; L. Ř e zník o vá, Identita/alterita [in:] L. S to r c hová et al., Koncepty a dějiny. Proměny pojmů v současné historické vědě [Concepts and History. Conceptual Changes in Contemporary Historical Science], Dolní Břežany 2014, pp. 233-243.

${ }^{2}$ L. F a s or a, J. Hanu š, T.W. P a vlíč e k (eds.), Kněžské identity v českých zemích (1820-1938) [Priestly Identity in the Czech Lands (1820-1938)], Prague 2016.

${ }^{3}$ Cf. H.H. Hahn (ed.), Stereotyp, Identität und Geschichte, Frankfurt am Main 2002.

${ }^{4}$ This approach does not consider identity to be a universally given and unchanging category. Indeed, the greater emphasis on the source clues enables the creation of a composite image of the life of a priest and incorporate his experiences into a wider social network. This was F. Fätkeheuer's understanding of the multiplicity of identity, Lebenswelt und Religion, Göttingen 2004, p. 17. 
of secularization, the modern age has generated a greater number of possibilities for individual choice and a greater number of areas of conflict where on almost a daily basis the priest has to test his level of loyalty towards the church and the willingness they have to introduce different types of changes.

Transformation in identity is seen as a change in loyalty towards a community, whether the impulse for that change comes from an emotional transition, a purely rational re-evaluation of a situation, or a combination of the two. By community we mean the church community in the Czech lands, which to a certain extent overlaps with the majority of society. In the modern era, the perception of community has been expanded (defined in terms of other religions, as well as political and national cultures), but the traditional links inside the community change and differentiate (the parish and the priest, the priest and the hierarchy, two national Catholic subcultures, etc.). Behind these changes is usually a transformed image of the enemy, who provides strong impetus for the formation of personal and group identities in terms of we/they. Therefore, in terms of historical research it makes sense to carefully monitor crisis periods, where the head-on collision with an enemy or opponent becomes an endurance test for groups as well as individuals, which sharply defines the contour of your own views and identity.

Where previous research into the issue of identity looked mainly at national identity, ${ }^{5}$ our group of authors deliberately took a slightly different view. We were interested in priestly identity as a professional identity, which at first glance might be similar to studying the identity of teachers, doctors or labourers - but only at first glance. Priestly identity is something altogether different and opens up a landscape of enquiry which is more segmented than for other professions, as here we are dealing with a vocation. If we look to German for help in distinguishing this key difference, then it is not a profession (Beruf), but a vocation (Berufung). In Christian society the priest offers a prayer on behalf of all of the believers, he brings a symbolic sacrifice to the altar, he distributes the bread of life, he confers God's forgiveness on the people. Priestly identity does not only mean being aware of membership of a group that really exists; it also means unity between the priest and the Gospel and the Church, Christ and his representatives, the priestly vocation, the parish and the nation.

\section{THE SPECIAL CHARACTERISTICS OF PRIESTLY IDENTITY}

Is there any point in taking an academic look at priestly identity? "I mean, for the non-believer a priest is an indecipherable enigma! It's only in the light of faith that you can understand the value of what he does and the sense of what he is. $\mathrm{He}$

\footnotetext{
${ }^{5}$ Here we must mention the "classic" of Czech research in this area by Miroslav Hroch and his latest book, cf. M. Hroch, Hledáni souvislostí. Eseje z komparativnich dějin Evropy [The Search for Connections: Essays in Comparative European History], Prague 2016.
} 
is obviously a man. Christ is invisible". ${ }^{6}$ Priestly identity is particularly complicated and difficult to understand using academic methods as it is connected to an effective mythical narration based on the perception of priestly spirituality, whether that be perceived positively or negatively. Let us look at two quotes which frame this mythic narrative. Alongside the bewitchingly spiritual "The priest is Christ who walks among us," is Elias Canetti's extremely sceptical statement, "Whenever priests have nothing to say, they mention God". ${ }^{\text {? }}$

The problems an academic has trying to understand a priest's identity cannot be limited to spirituality. When researching priestly identity, the Early Modern Age and the Modern Age are extremely interesting and inspiring, yet at the same time they are incredibly difficult. The priests were affected by dramatic changes in their social standing, public prestige, the appreciation of their education, demands from the hierarchy, as well as in terms of their safety. For centuries the priest had been able to rely on the stability of his position in terms of prestige, relative prosperity, the exclusiveness of his education and on the safety of his power. The modern era ground those certainties into dust. The solitude of the priest and his reflections upon it became one of the most difficult tests of his loyalty and one of the battlefields in the crisis of identity. The priest found himself laid bare, far away from social initiatives, attacked during his religious activities, gradually removed from community, work, the authorities and the power to influence anything. ${ }^{8}$ His solitude was framed by his celibacy, which was viewed with extreme sensitivity as the main reason for, and symbol of, his separation from the everyday life of ordinary people. In the modern era, the priest gradually acquired the sorrowful position of a suffering relic from a bygone age, whose testimony was being heard by fewer and fewer people.

The literature to date tends to focus on the closing period of this transformation. The most recent work by a group around Jiří Hanuš also examined priestly identity in the $20^{\text {th }}$ century; ${ }^{9}$ the focal point of which was an analysis of the relationship between the priesthood and the three crucial regimes of the period: there was an emphasis on the relationship with the "Hussite" Czechoslovak Republic, though with significantly less on the relationship towards the Nazi regime, while there was far more on communist totalitarianism. The publication Priestly Identity examines the early period; it attempts to investigate the beginnings of the processes, the wider ramifications and social impact of which would be felt in the $20^{\text {th }}$ century, but whose roots go far back into the $19^{\text {th }}$ century. And within this time frame we consciously scaled back on Czech developments in comparison with western Europe, and France in particular, where we could easily have gone back even further into the past in our study of how priests were affected by local developments. Here, on the very territory of the "first daughter of the Church", priestly identity was fundamentally shaken by a dispute between ordained and unordained priests - a dispute which was to divide religious France for

${ }^{6}$ L. S a pi en za, Muž Boži. Stránky o kněžské spiritualitě [Man of God: Writings on Priestly Spirituality], Olomouc 2009, p. 3.

7 Ibidem, p. 24.

${ }^{8}$ Ibidem, p. 15.

9 J. Hanuš et al., "Služebníci neužitečni".... 
several decades. ${ }^{10}$ Generally it can be stated that almost all of the dynamic changes and revolutions in the modern age affected the priest's identity. During times of prosperity and progressive change, interest in the priestly vocation waned or the clergy were used in a utilitarian fashion (e.g. for consecrating association banners); in hard times and times of war the priest was sought out to intervene and ask God for help and redress. ${ }^{11}$

Our project's time parameters are framed on the one hand by the attempts of the popes to renew the authority of the Roman Catholic Church following the French Revolution and the Napoleonic Wars, which includes the activities of Pius VII and Gregory XVI, and how they were received in the Czech lands, up until the interwar Czechoslovak Republic and its struggle to reach a consensus with the Catholic Church. One dominant theme in terms of the "image of the enemy" is that of liberalism in its various forms, including liberal Catholicism and Catholic modernism. Naturally the theme of socialism is to be found here in many cultural aspects as the intellectual heir to liberalism, and from the mid-19 $9^{\text {th }}$ century as a much larger and more dreaded enemy of Catholicism.

In comparison with the situation in 2015, when the important and inspirational Služebníci neužiteční [Useless Servants] ${ }^{12}$ was published, much has changed in the field of religious history research in the Czech Republic. Thanks to financial support from the Czech Republic Grant Agency, it was possible to mobilize researchers who were interested to a greater or lesser degree in the theme of priestly identity, in some cases tied to small-scale solitary research work, while overall there was an interest in reviving this interesting and important area of historical research. Thanks to this, the research group could risk something on a larger scale and attempt to understand a theme encapsulating an incredibly colourful portfolio of priests, their lives and identities, using a disciplined, unified approach in the main outlines of their work.

That is why the project reflects the diversity of the priesthood in seven respects. The first is the generational dimension, where thanks to quantity, erudition and enthusiasm it was possible to give a representative account of the generations of priests connected with this era, and thus examine more carefully the crisis of identity and areas of conflict. We started from the proposition that for the theme of identity it was necessary to analyse the generational experience and the horizon of the generational consciousness, as proposed by Karl Mannheim and his followers, without which it would be impossible to imagine any way to generalize the findings from our biographical studies. ${ }^{13}$ There are in fact two advantages from this approach: a more precise classification of generational units and an emphasis on the mutual proximity of priests who shared similar views as a consequence of living through similar

${ }^{10}$ Cf. M. Burleigh, Pozemské mocnosti. Politická náboženství od Velké francouzské revoluce do 1. světové války [Earthly Powers: Political Religion form the Great French Revolution to the World War I], Prague 2016, pp. 61-80.

${ }_{11}$ The social imporatnce of relgious intervention is more important than a theological system for the identity of a community. See M. Ri e s en brodt, Cultus und Heilsversprechen, Munich 2007.

12 J. Hanuš et al., "Služebníci neužitečni'”...

${ }^{13}$ Cf. for example M. Corste n, Čas generaci [The Time of a Generation], "Sociální studia” 2007, vol. 4, no. 1-2, pp. 46-65. 
historical events and turning points, even though they may have belonged to different age groups. It is also impossible to overlook aspects of nationality, or more precisely, nationality and language, and the vital difference between the perception of individual identity and group identity by Czech- and German-speaking priests, i.e. by Czechs and Germans. National identification significantly influenced attitudes towards the state and provincial authorities, and the idea of the state. With the gradual drifting apart of Czech- and German-speaking societies in the last third of the $19^{\text {th }}$ century, the priest also had to address the serious issues of loyalty to the nation, province, state or Rome. ${ }^{14}$

The third, fourth and fifth aspects are how these differences were reflected in how the priest carried out his work. The actors who are analysed in the book include regular, secular, diocesan and lay priests. Some of them were firm in their loyalty to Rome and their fellow brethren, but were interested in the local and provincial conditions at the expense of papal authority. We also examine the relationship between the priest and power, i.e. his position on a notional scale ranging from a pastoral type to a powerful type. This is certainly a problematic aspect, particularly if we recall the Archbishop of Olomouc, Antonín Cyril Stojan (1851-1923), a man with great power whose pastoral and humanitarian reputation superseded the boundaries of his diocese as well as time. Nevertheless, this scale is a useful research tool and important for drawing general conclusions.

We also managed to capture (albeit with a problematic source base) the differences in the development and realization of priestly identity in urban and rural settings. The differing tempo of capitalism, the liberalization of society, the growth in religiosity and a range of other aspects led us to emphasize the differences in the communication networks which urban and rural priests had, which implies a different form of source base and a somewhat different emphasis in the research enquiry. In terms of the proportionality of the group, the final challenge was the difference between priests whose daily lives focused on the narrow performance of their duties and priests who were more publicly active outside of their office and parish. This could be mundane work for a club or society, or work which was more visible, such as in politics, science or art. It is certainly not difficult to find the required sources

${ }^{14}$ Cf. for example T.W. Pavlíč ek, Katholizismus in der Moderne. Religiöser Wandel und die Positionierung des Klerus in Böhmen und Bayern in der zweiten Hälfte des 19. Jahrhunderts [in:] M. H1 a vačka, R. Luft, U. Lunow (eds.), Tschechien und Bayern. Gegenüberstelungen und Vergleiche vom Mittelalter bis zur Gegenwart, Munich 2016, pp. 169-184; M.C. Putna, Česká katolická literatura $v$ evropském kontextu 1848-1918 [Czech Catholic Literature in a European Context], Prague 1998; L. F a sora, J. Hanǔ́, J. Malíř (Hg.), Sekularizace českých zemí v letech 1848-1914 [The Secularization of the Czech Lands from 1848-1914], Brno 2007; F.X. Ha la s, Fenomén Vatikán. Idea, dějiny a současnost papežstvi [The Vatican Phenomenon: The Ideas of the Papacy throughout History and Today], Brno 2004; M. Havelka, Ke dvěma intencím procesu sekularizace v 19. a 20. století [Towards Two Intentions of the Process of Secularization in the $19^{\text {th }}$ and $20^{\text {th }}$ Centuries], "Lidé města" 2009, 11/3, pp. 441-462; Z.R. N eš por, Náboženství na prahu nové doby. Česká lidová zbožnost 18. a 19. století [Religion on the Threshold of a New Age. Popular Czech Piety in the $18^{\text {th }}$ and $19^{\text {th }}$ Century], Ústí nad Labem 2006; Z.R. N e š p or, Náboženstvív 19. století. Nejcírkevnějši století, nebo obdobi zrodu českého ateismu? [Religion in the 19 $9^{\text {th }}$ Century: The Most Religious Century or the Period of the Birth of Czech Atheism?], Prague 2010. 
for this group of publicly active priests. The problem here is that the historian can be literally deluged with sources and has to struggle to evaluate them and provide an interpretation of identity, as it was these very publicly active priests who faced the stiffest tests.

\section{CONFLICT LINES AND PROBLEM AREAS}

When defining our project goals, we tried to direct the team towards those conflict lines which have been viewed by historians as significant for the further development of Catholicism in the Czech lands. We had no doubts about the significance of the First Vatican Council, the Second Confessionalization, Catholic modernism, the radicalization of society during World War One, and the importance of the complicated relationship between the Catholic Church and the interwar Czechoslovak regime. However, we also felt that the research to date could have focused more on the development of the Church and society before the First Vatican Council, as well as on some internal conflict lines within the Church. The most important of these include the changes to the authority of Rome and the episcopate, conflicts with the prevailing culture and the political mainstream, as well as conflicts arising from the complicated economic position of the clergy. And as we have already mentioned, we assume that these conflict lines had an impact on individuals.

Was there a definition of an ideal priest during this period? Although it is necessary to examine the definition of the ideal and its influence on each student at the seminary, or on novice priests, its importance should not be overstated as this could affect the responsiveness required when looking at each individual's own path. However, for the historian the significance of the ideal cannot be overlooked as it plays a large role in Christianity and each priest in his vocation is following Christ. Naturally, from a methodological viewpoint the attention given to the ideal also opens the door to doubt. When trying to construct a representative portfolio of priestly identities in our book, it has to be admitted that it is nothing more than a paradigm we are working with in an effort to model the various forms of a priest's vocation. ${ }^{15}$ The thousands of priests who did not leave enough relevant sources behind them (thus escaping the attention of historians) presumably reflected on the definition of the ideal. How else might one approach the notes in the consistory collections, which assessed the priests and their parishes in positive terms and did not record any significant deviations from the norms of the period?

In any case, the "priestly ideal" is a historical phenomenon in the sense that - at least in the modern age - there is not one shared model (apart from the founder of Christianity, who is naturally the source). Although even here it is the case that different historical periods have stressed different aspects of Jesus's personality, albeit

15 This approach does not search for just one universal type of priest, but it provides a picture made up from the individual experiences of various priests. Cf. F. Fätke n h e u er, Lebenswelt und Religion. Mikro-historische Untersuchungen an Beispiel aus Franken um 1600, pp. 14-15. 
based on a theological interpretation of the New Testament. This is especially true for other models - in the Czech lands in the $19^{\text {th }}$ and $20^{\text {th }}$ centuries there appeared several "model matrices"; from the enlightened priest looking after the well-being of his earthly community, through to the unorthodox Bolzano-inspired intellectual and romantic "priest of the people", to the universal scholar of rehabilitative nationhood, struggling against totalitarian regimes. ${ }^{16}$

As part of the project the authors were given four areas which formed the basis and guidelines for working with the biographical material:

a) Identity as the disposition of power, i.e. part of one's own identification with power. It is necessary to look for the answer to the following questions: do specific individuals identify with their profession and the role its power has in society, while conscious of the fact that it is not a profession in the strict sense of the word, but a vocation in touch with the "supernatural" world (Beruf/Berufung)? How does this consciousness of power relate to being aware of a firm and unbreakable tie to the "Mother" Church, specifically the episcopate and the ideas of Christianity? Why are some of the aforementioned areas weakened, suppressed and transformed over time? How does the sharing of this disposition of power manifest itself during difficult times when there is a feeling of powerlessness regarding steps taken by the episcopate which were felt to be wrong or conflictual (a question of faithfulness, loyalty)? How does the pastoral role of the priest compare in people's eyes with the real or imagined share in power, what tools will the individual be willing to use in the instruction or discipline of the people around them in order to assert their own authority?

b) Identity as the consequence of conflict with opponents. The awareness of identity, its reconstruction and strengthening can be the result of participating in a struggle between Church/faith and non-belief. This acts against the values rooted inside oneself - it is an alternative project, perceived as competition and a threat, which impacts on the whole of society, morality and even on the demise and birth of countries. A similar conflict need not only be within the Church, but could also be internal - does it also take on the form of a personal crisis?

c) Identity as a source for mobilizing and motivating behaviour. Do specific individuals have a perceived ideal of what a priest's vocation entails? Is this viewed with critical distance as a myth, i.e., an interpretation of reality supported by the power ambitions of the harbinger of the myth, or is the identification profound and complete and does not contain an awareness of the mythical aspect? Is the confrontation of the ideal with reality a stimulus to resolve their own real or perceived conflicts? What is the relationship between the awareness of an eternal ideal and the awareness of their own politcal-power position and the issue of loyalty?

d) Identity as a consequence of the expectations of others. In which communication networks did the specific person find themselves in, where were the possibilities or likelihood of contact, including associates from a social, intellectual or national perspective? In which communication networks were the themes of the role and identity of the priest explicitly articulated and contextualized, and where was it

${ }^{16}$ The issue of types of priests in the modern age can be found in older works, e.g. J. Ka dlec, Přehled cirkevních českých dějin [An Overview of Czech Religious History], vol. 2, Rome 1987. 
more about the implicit articulation of these themes, such as debates about specific problems of morality, etc.? Were individual priests aware of the various expectations on the part of believers, the episcopate, subordinates, other priests, and how did they deal with these expectations and pressure from the disciplining process?

The individual authors were asked to focus as much as possible on these areas, even at the expense of biographical details which would be irrelevant for these questions. On the other hand, the editors left a certain freedom when outlining the individual portraits, in order not to restrict the author's individual style and to produce a variety of experiences and expectations from life, even from one generation of clerics. It is clear that when writing the biographies it would be necessary to focus not only on a predetermined series of questions, but principally on the specific characteristics of individual people's lives. This might even highlight the inspirational tension between social-scientific and historical questioning.

An analysis of thirteen biographies from 1820-1938 relating to priestly identity showed several typical signs linking a relatively long period of time, as well as a whole series of identity-specific signs. When summarizing the research findings, a useful aid was the application of a basic range of positions towards the world and one's own identity, based on the above-mentioned polarization of self-confidence on the one hand, and uncertainty and frustration on the other. However, before placing the actors from our research onto this scale, we will briefly outline their lives and the age groups to which they belonged.

Jan Valerián Jirsík (1798-1883) - ordained in 1820, parish priest, canon of the metropolitan chapter, $4^{\text {th }}$ bishop of České Budějovice, theologian, writer and patriot........................ Rudolf Svoboda

Jan Zátka (1802-1881) - ordained in 1827, catechist in Písek, chaplain in Velešín, professor of religion in Jindřichov Hradec, biblical scholar, philosopher and follower of Bolzano's teachings... Miroslav Novotný

Beneš Metod Kulda (1820-1903) - ordained in 1845, chaplain in Brno, parish priest in Chlum and vicar of Sedlčany, canon of Vyšehrad, writer and editor...... Tomáš Zouzal

Antonín Lenz (1829-1901) - ordained 1854, professor at the diocesan academy in Budějovice, provost of Vyšehrad, theologian and apologist..... Tomáš Veber

Andreas Hamerle (1837-1930) - ordained in 1863, provincial superior of the Redemptorists, writer, homiletic and people's missionary working with Czech Germans.................. Kristina Kaiserová

Ambros Opitz (1846-1907) - ordained in 1870, chaplain in Varnsdorf, founder of the Christian-Social Association of Czech Germans, editor, publisher and apologist... Kristina Kaiserová 
Karel Habersberger (1849-1916) - ordained in 1874, chaplain in Benešov, parish priest in Rousínov confronted by the anticlerical and "Hussite" campaign by Alfons Št’astný.......... Tomáš W. Pavlíček

František Zapletal (1861-1935) - ordained in 1884, Alumnus in Rome, Ultramontanist, vice-rector at the Czech College in Rome, provost of Vyšehrad, auxiliary bishop in Prague.... Jitka Jonová

Jan Pauly (1869-1944) - ordained in 1892, chaplain in the working-class district of Smíchov in Prague, representative of the Provincial Unity of the Catholic Clergy in Bohemia, Archdeacon of Smíchov, Prague vicar, canon of Staroboleslav Markéta Skořepová, Tomáš W. Pavlíček

Jakub Deml (1878-1961) - ordained in 1902, nonconformist priest, poet and translator, author of The Forgotten Light............... Jiří Hanuš

Emanuel Masák (1883-1964) - ordained in 1907, chaplain, catechist, writer and editor, moderate modernist...... Petr Husák

Bohumil Stašek (1886-1948) - ordained in 1909, chaplain, vicar at Vyšehrad, secretary of the Czechoslovak People's Party, member of the National Assembly, interned in a concentration camp. Jaroslav Šebek

Eduard Winter (1896-1982) - ordained in 1919, theologian, historian, leader of the Staffelstein Association of German Intelligentsia, professor at the German University in Prague, member of the NSDAP, member of the GDR Academy of Sciences............... Miroslav Kunštát

\section{A HISTORY OF THE INTEREST IN PRIESTLY IDENTITY}

Interest in analysing priestly identity in a church context, and subsequently a scientific one, grew as a result of the Second Vatican Council and the proverbial "open windows" in the Catholic Church in the 1970s and 1980s. Naturally, there were already discussions about the priestly vocation amongst theologians at the start of the $20^{\text {th }}$ century. ${ }^{17}$ There were probing sociological analyses in Czechoslovakia in the 1930s by re-

${ }^{17}$ E.g. a seminar given by Louis Brancherea in Orleans in 1896 presented a thesis on the necessity of looking for subjective inclinations towards the priestly profession, which is confirmed by the ecclesiastical authorities at the consecration. In opposition to this, Dax Joseph Lahitton stated at a seminar that the profession is a matter dealt with directly and only through the bishop, which was also confirmed by a papal commission. U. Feeser-Lichterfeld, Berufung. Eine praktisch-theologische Studie zur Revitalisierung einer pastoralen Grunddimension, Münster, pp. 219-220. 
searchers such as Jaroslav Šíma. ${ }^{18}$ The research from the period of the Second Vatican Council is valuable because it examined both the Catholic Church and other Christian churches. In Germany and Austria, bishops' conferences commissioned impressive sociological research, ${ }^{19}$ which introduced issues to the academic sphere which are still being dealt with today by both the Church and from an academic perspective by sociologists of religion, as well as theologians and historians. This sociological research, and the subsequent work which was influenced by it, has a clear limitation which is difficult for historians to accept - the strict chronological delimitation. Quantitatively-based sociological analyses of priestly identity in Central Europe only cover a few decades. However, historical research has to go significantly beyond this time scale and develop a specific set of methods which allow us to look beyond the time parameters of sociological questionnaires and methods of oral history.

Biographical work is one of the most difficult areas of heuristics, and so in this light perhaps any attempt to analyse priestly identity as far back as the first decades of the $19^{\text {th }}$ century would appear to be very ambitious. The theological projects which were carried out at Innsbruck University have so far only reached 1900. As these were analyses based on biographical material relating exclusively to members of the episcopate or professors of theology at Innsbruck and Vienna University, their value is somewhat limited in terms of being representative of the clerical profession. ${ }^{20}$ In addition, the chosen time parameters seem to be essentially random, selected mainly as the outermost position of the approach, and are not directly related to the crisis of modernism in religious communities and the Catholic Church in particular, as was stated by Karl Gabriel and Franz-Xaver Kaufmann, who associated the start of this crisis with the First Vatican, ending with the Second Vatican. ${ }^{21}$ Understandably, it is not possible to go far with an analysis of identities with such a rigid time frame, and, therefore, it is necessary to devote some attention to the events which occurred before and after these important milestones in the history of the Roman Catholic Church. While historical sociology has managed to analyse events after the Second Vatican, it remains a challenge for historical science to apply this to the First Vatican and the period preceding it. Here there is also the issue of defining borders and historical milestones. The councils are turning points par excellence,

18 J. Š í ma, K sociologii duchovniho [Towards a Sociology of the Clergy], Praha 1937.

${ }^{19}$ G. Schmidtchen, Priester in Deutschland. Forschungsbericht über d. im Auftrag der Deutschen Bischofskonferenz durcheführte Umfrage unter allen Welt- u. Ordenpriester in d. Bundesrepublik Deutschland, Freiburg-Basel-Wien 1973; O. S chreu der, Der alarmierende Trend. Ergebnisse einer Umfrage im gesamten holländischen Klerus, München 1969-1970; P.M. Zu le h n e r, Kirche und Priester zwischen den Aufratg Jesu und der Erwartungen der Menschen, Linz 1974; P.M. Zu le h n e r, Priester im Modernisierungsstress, Ostfildern 2001; J. K erk h o fs, P.M. Zu le hn er, Europa ohne Priester?, Düsseldorf 1995; Ch. Fries l (ed.), Christen als Beruf. Chancen und Problemfelder theologische Karrieren, Innsbruck-Vienna 1996, summarized by B. P i k l b a u e r, Priesteridentität zwischen Kirche und Gesellschaft, Linz 1998; also: Christen als Beruf, Vienna-Innsbruck 1996.

${ }^{20}$ P. F e r n e r, Hirte oder Herrscher? (doctoral thesis, Theological faculty, Innsbruck of University), Innsbruck 2009, pp. 249-294.

${ }^{21}$ B. Pirk 1 baue r, op. cit., p. 150; srov. K. Gabrie 1, F.-X. Ka u fma n n, Zur Soziologie des Katholizismus, Mainz 1980; K. Gabrie 1, Christentum zwischen Tradition und Postmoderne, Freiburg-Basel-Vienna 1992. 
although principally within the traditional understanding of church history. More recent historical disciplines which emerged midway through the $20^{\text {th }}$ century would tend to be more sceptical about these milestones, if not directly reject them. For example, the Ultramontanist relationship between the clergy and the pope concerning papal infallibility has been discussed since the 1930s, and was defined absolutely by the famous dogma at the Council. ${ }^{22}$

The valuable line of questioning, which combines the approach of historians with the approach of sociologists, defines aspects of priestly identity and attempts to create a typology. In the study of priestly identity, sociologists and historians regard sub-topics such as psychological personality characteristics as relevant, along with the relationship with the institution, the issue of spirituality and the subject of the expectations of society and those in contact with priests. A balanced relationship between the aforementioned segments of a priest's personality has a significant impact on the state of his identity. Christoph Victor attempted to classify pastors from the Lutheran Evangelical Church of the Augsburg Confession into six types, mainly taking into consideration sociological research linked to the present day with a retrospective aspect reaching back to the $1980 \mathrm{~s}^{23}$ :

- the self-confident type whose own upbringing in childhood and youth has a strong link to Christian and at the same time humanistic values; the study of theology provided him with a very robust foundation for an awareness of the guiding role of the church and his own self in various social roles;

- the self-confident spiritual type adds to the above a lively spirituality, a knowledge of various forms of religious life and an ability to develop a spiritual life befitting himself and those around him;

- the self-confident type with a tendency to cross boundaries puts to use his ability to discover and direct new, often original forms of social encounter and community life; spirituality does not have the same importance for him as for the previous type - in its place he sets an organizational role and the respect it brings within the community and church;

- the uncertain type had a family humanistic or Christian-humanistic upbringing and studied theology, and yet this foundation of identity has been buried under the weight of other work and does not determine his everyday life; for him, spirituality is not developed in a creative way, and he loses his bearings in how to deal with perceived social problems - although he sees various possibilities and opportunities in his surroundings and in the community, because of overloading and feelings of isolation he does not dare to put forward his own vision;

- the frustrated type started out from an upbringing based more on humanistic and ethical or moral norms than on a Christian upbringing - the priestly profession was not his original choice and he preferred a secular profession;

${ }^{22}$ H. Küng, Unfehlbar? Eine Anfrage, Zürich-Einsiedeln-Köln 1970, p. 15; also cf. H.J. Pottmeyer, Unfehlbarkeit und Souveränität. Die päpstliche Unfehlbarkeit im System der ultramontanen Eklesiologie des 19. Jahrhunderts, Mainz 1975.

${ }^{23}$ C. Vic tor, Pfarrer sein in wechselnden Gesellschaften. Eine Quantitative Untersuchung zu Identität und Alltag im Pfarrberuf, Leipzig 2005, p. $211 \mathrm{ff}$. 
theology and spirituality do not determine his everyday life, since he deems it impossible to put Christian ideals into practice - he therefore refuses to take on the responsibility for some projects regarded by those around him as part of the role of a priest;

- the frustrated type within the limits of time and situations differs from the aforementioned type in his fluctuations - he is prepared to tackled a defined problem in a declarative way and overcome difficulties, but without outside support and supervision his efforts quickly give way to a search for reasons for failure.

We do not see the typology presented here as being applicable to the Orthodox Church or to some branches of Protestantism. However, this typology, although originally developed for a different period, holds up from our point of view when applied to Roman Catholic priests, since its determining criterion is the mutual link between priestly spirituality, the power position of the church and the expectations of society - a link which was therefore important for every church which laid claimed to an important position in an open or opening-up society, i.e. to a prominent role in the process which Central European and Czech society underwent in the period under observation. ${ }^{24}$ What is important for us here is not the transfer of this typology into the historical period but rather the similarity of the historical development, in which the relationship between the clergy on the one hand and the church, state and society on the other was constantly being "renegotiated" from the beginning of the $19^{\text {th }}$ century onwards. ${ }^{25}$

\section{GENERATIONAL AFFILIATION OF PRIESTS 1820-1938}

The set includes priests from all the generations of the period under observation. With the backing of the generational experience of key events, which noticeably bring a generational unit closer together, it is possible to work with a thesis of:

- the pre-1848 generation, shaped during their studies by the experience of coming to terms with echoes of the Enlightenment in the form of the restoration alignment of the Austrian state and church and seeking an inner renewal of the clergy and laymen during their pastoral work (Jirsík, Zátka);

${ }^{24}$ In this regard the books by the Czech Protestant theologian Pavel Filipi, in which he explores the relationship between churches and their teachings in relation to society, are thought-provoking, cf. e.g. P. Filipi, Křest'anstvo. Historie, statistika, charakteristika krest'anských církví [Christianity. The History, Statistics and Characteristics of Christian Churches], Brno 2012.

${ }^{25}$ Until the end of the 18th century, the role of the clergy in the liturgical system was practically unchanged, unchallenged and economically profitable. Cf. J. Š otola, Kariéra v černém. Předpoklady pro ziskáni beneficia v 18. stoleti [A Career in Black: Requirements for Obtaining a Benefice in the 18 ${ }^{\text {th }}$ Century], “Ćasopis Matice moravské” 2007, vol. 126, no. 2, pp. 319-341; T. Malý, Spása a smrt mezi Tridentinem a sekularizací. Brněnští měšt'ané a proměny laické zbožnosti v 17. a 18. století [Salvation and Death Between the Tridentine and Secularization: The Brno Bourgeoisie and Changes in Lay Piety in the $17^{\text {th }}$ and $18^{\text {th }}$ Centuries], Brno 2009. 
- the generation of revolutionary upheavals in society and the (Austrian) Catholic Church, i.e. the generation who during their studies or shortly after ordination placed great hopes in the revolution of 1848, or the Concordat of 1855 (Kulda, Lenz, Hamerle);

- the generation who were shaken during their studies by the revocation of the Concordat and the legislative interventions of the state during the era of Austrian liberal governments from 1861 to 1879 , i.e. the generation torn between respect for the resurgence of the church and doubts about whether the conservative route was the right one - in other words, the generation determined to subsequently put new evangelical techniques to use or to strongly align themselves - in an Ultramontanist way - with the pope (Opitz, Habersberger, Zapletal);

- the generation affected fully and in the most heart-rending way by the crisis of modernism, achieving the highest degree of pluralism in response to it, in connection with the initiatives of the national society and its culture (Pauly, Deml);

- the generation of the postwar regeneration of Catholicism in the Czech lands, experiencing with embarrassment the association of the Catholic Church with the Czechoslovak state and democracy and in general the era of a certain restrained modernism in domestic Catholicism, which quietly adopted some of the modernists' visions while rejecting other (usually more significant) ones or sought new pastoral stimuli beyond the borders of domestic (Czechoslovak) Catholicism (Masák, Stašek, Winter).

The set contains both figures from the higher echelons of the church hierarchy and figures whose career either had limits set at a generally low level or was predominantly realized outside the church hierarchy, in the everyday world of traditionally defined pastoral work. The choice of individuals respects the ethnic composition of the Czech lands and also reflects the dividing line between the city and the countryside as well as the difference between priests from religious orders and diocesan priests, also called secular priests. The form of the set is clearly limited by the state of the source base. With regard to the generational typology in particular, which we perceive as very valuable, further completion is therefore desirable. Although specific groups of priests are well represented in the entire set, this is not the case with individual generations. Among the cohorts ordained after the First Vatican Council, there is considerable internal divergence on the question of the role they should play in society. The reasons for this were not always ideologically Ultramontanist ones, because marked differences in the economic position of the clergy can be seen among priests who had secured advantageous benefices for themselves before the revocation of the Concordat and those who registered for open competitions for parish positions after the economic crisis in the 1870s. The conclusions drawn from the analysis of the biographical profiles can therefore in this respect be perceived as a challenge for the further expansion of the research, for which we are attempting to present the academic community with an interpretational proposal or guideline, especially with regard to work of a qualifying nature.

The research points to a strong esprit de corps in the priesthood as a result of the shared formative experience of education in a seminary. The consciousness of the church's authority as the upholder of order and tradition had particular 
significance, with everything being framed by the acceptance of the idea of the importance of the church hierarchy, the pope and the Roman curia. The representatives of the priesthood who make up the set were accompanied throughout their lives by this set of identity-forming symbols, as a very clear dividing line marking the border between consistency and inconsistency of personality. The rejection or basic relativization of this border became the precondition for a fundamentally different stance towards life and the world. Jakub Deml in particular, the most complicated and internally conflicted individual in our set, operated right on that border, and sometimes even beyond it, on a long-term basis. Seminary education had a very similar effect on candidates for the priesthood. It seems that it is possible to speak of a certain universalism associated with seminary education, which quite effectively eliminated social and national differences and transformed the individuality of seminarists into a common denominator of usefulness to the church, as indicated above. However, upon commencing pastoral work, each newly ordained priest quickly found himself in some degree of isolation and had to "renegotiate" his identity in relation to his conviction (vocation), to the church hierarchy, to the patron of the parish and the religious community. This situation gave rise to desires to create priestly collectives (associations, congresses, journals, priestly vocal ensembles etc.) and at the beginning of the $20^{\text {th }}$ century also to an increased interest among priests and laymen - both men and women - in a monastic or simply community-based way of life.

If seminary education represented an assumption of strict discipline within the priestly community and the entire church, then priests linked with the Roman institutions through their education formed the crème de la crème of the church in the Czech lands. Here the rise in the influence of the papacy together with the authority of Ultramontanist politics was amply demonstrated. The episcopal seminary offered basic guidance, but - as is shown by some examples, and not only Deml's - this did not necessarily mean immunization against doubts about the purpose of the priesthood ${ }^{26} \mathrm{~A}$ "Roman" education and connections were such an unambiguous orientation in the life of a priest that they effectively created a social niche which had an immunizing effect on the impact of doubts originating in this country. In terms of the quality of their education and their overall outlook, the "Romans" tended to outstrip the usual domestic standards and therefore necessarily demonstrated their superiority in their efforts to secure influential posts in the church hierarchy, without it being possible to speak explicitly of some form of "Roman conspiracy". This also manifested itself throughout the $20^{\text {th }}$ century, even though graduates from Roman courses of study were often not able to operate in the domestic environment because of the altered conditions. On the other hand, it is necessary to ask how the clergy ordained in the episcopal seminaries, whose career options (consistory members) and opportunities for financial security (canonical posts) were newly restricted, faced up to the "Roman" elite. It is therefore a research challenge for

${ }^{26}$ J. Oli č, Čtení o Jakubu Demlovi [Readings on Jakub Deml], Olomouc 1997; J. D e m 1, Zakázané světlo. Výbor z korespondence z let 1930-1939 [The Forbidden Light: A Selection of Correspondence from 1930-1939], Prague-Litomyšl 1999, pp. 99-100; M.C. P u tn a, Česká katolická literatura v evropském kontextu 1848-1918 [Czech Catholic Literature in a European Context], Prague 1998, p. 475. 
the future to analyse in greater depth the role of the "Roman" priests within the community and shared/differing attitudes to key events within a single generational unit. Biographical sources from this country are unlikely to suffice, and further clarification of this complicated question can be expected more from international, probably Central European comparisons.

The key role of the seminary in shaping priestly identity concealed two problems that came to the surface because of the deep crisis of modernism with the Catholic Church, which fell within the period under observation. The first of these problems was the very nature of formation in the seminary, which in the Czech lands around the 1870 s gradually began to move away with increasing speed from public expectations of the role of the priest, as well as from his pastoral activities and public work in general. The 1870s saw the beginning of a divergence between the trajectories of the Catholic Church and the Czech national movement, with hints of this process already manifesting themselves in the revolutionary years of 1848-1849. In the Czech ecclesiastical province, Archbishop Bedřich Schwarzenberg (in office 1850-1885) managed to carry out internal reforms to church life up until the end of the 1860s, which were welcomed by (especially Czech) clergy across the social hierarchy. However, the Roman Catholic Church, constrained by the outcome of the First Vatican Council, had lost the previous vigour which some priests had demonstrated in relation to the process of Czech national emancipation. In our set, this dilemma is particularly represented by Jan Zátka, but a better-known case is the fate of the circle of patriotic priests around František Sušil (1804-1868). ${ }^{27}$ The aforementioned loss of vigour or increase in doubts about whether it was right to go down the route of the national movement reinforced the confrontation of the Catholic Church with the pluralization of Czech public life, and especially with growing liberalism, which manifested itself in the increased self-confidence of the Czech patriotic elites. Although the project of the Czech national revival was then carried on mainly by educated sections of Czech society, priests were increasingly excluded from their circle or rather quietly ignored. The revocation of the Concordat, the conclusions of the First Vatican Council, the legislative interventions of the liberal government and the financial restrictions affecting the church (and the Náboženská matice fund) after the financial crisis played into the hands of the Ultramontanist positions and strategies of the new Prague archbishop Franz de Paula Schönborn (Archbishop of Prague 1885-1899).$^{28}$ In the eyes of their educated secular partners - and often also of their rivals such as lawyers, teachers, doctors etc. - priests stigmatized by the rigidity of Roman politics and fettered by the typically Austrian alliance of throne and altar became a limiting, inadequate and even suspicious partner for the national movement in its increasingly ambitious objectives. Even if this development

${ }^{27}$ T. J i r o u š e k, Dějiny sociálniho hnutí v zemích koruny české 1840-1909 [A History of the Socialist Movement in the Czech Crown Lands], vol. 1-3, Prague 1900-1909; V. F rol c o vá, František Sušil (1804-1868), odkaz a inspirace [František Sušil (1804-1868), Legacy and Inspiration], Rousínov 2004.

${ }^{28}$ The activities of both Archbishops of Prague is an example of the dynamics of historical change, in part because both Prince Schwarzenberg and Count Schönborn have chaired the Austrian Bishops' Conference. 
exhibited a number of regionally specific aspects and, especially in peripheral areas of the Czech lands, it is necessary to analyse the mutual relationship of the Catholic Church and the national movement using very delicate instruments, it is still possible to speak in general terms of the dramatically increasing alienation of the two institutions, with the lack of understanding reaching its peak roughly in the decade before the World War One and during it.

From the point of view of the church, with the acceleration of social changes in the aforementioned decade, the life-giving emphasis on tradition and legitimacy turned into a useless and incomprehensible rigidity which threatened to destroy the influence of the church, or at least significantly weaken it. The introduction of etatist practices to public education, the accessibility of higher education in languages other than just German, and also the increasing density of the network of grammar schools and the scientization of the activities of universities - all of these phenomena exposed priestly education in the Alumnat seminaries and at the theological faculties to the danger of isolation and losing touch with the expectations the public had of members of the educated elite. For the identity of newly ordained priests, this meant that there was a dramatic increase in the difference between their own expectations associated with the priestly vocation and the public respect and authority it enjoyed, and the reality of the increasingly lukewarm attitude of the public, contempt from the male section of the population and especially the consciousness of their own inability to respond to public demand and "challenges" in a way that was not based on power. The role of Rome, the importance of tradition and the whole system of conservative values bound up with what was happening in the church did not permit an appropriately fast and effective response to this development, although many priests in higher positions within the hierarchy were aware of the need for change. In this regard it is necessary to take into account the importance of the phenomenon of anticlericalism, which within the Habsburg monarchy mainly concerned the Roman Catholic Church, and its characterization and main themes can be observed primarily in the liberal and social environment. However, some elements of it soon infiltrated churches too, causing a rise in the internal polarization of the Christian community.

The advantage of the Alumnat seminaries, fixed since Tridentine times, was their systematic and independent (from the state) work with youths at an age when their cognitive awareness of public affairs was reaching its peak. In the period under observation, the minimum age for Alumni (students at an Alumnat) was higher than it had been in the early modern age, when it was possible to accept boys from the age of 12 . Nonetheless, they were still young men who had demonstrated a certain spiritual disposition in their previous studies (having graduated in philosophy or passed their school leaving exam) and who were still at the age of heightened emotionality, which in the seminary under expert guidance could be attached to religiosity, tradition, authority and the social usefulness of the church - one example is the seminary of Bishop Jirsík. However, the set of priestly biographies that was analysed reveals complaints by priests, appearing in contemporary visitation reports and minutes from pastoral consultations, about their isolation in the face of development that was so complicated for the priesthood, and thus about a lack of support from both the hierarchy and their fellow brethren (e.g. Karel Habersberger). This 
constitutes a serious flaw in the entire system of the church's personnel policy, if we can call it that. During the crisis of modernism, it proved unsustainable for a systematic and across-the-board effort to strengthen priests' sense of fellowship with the church, the bishops and, no less importantly of course, Christ's legacy to be limited de facto to the youth, the period around ordination and the relatively short time spent working as a curate under the supervision of a more experienced clergyman. The development of a system of pastoral consultations on centrally determined topics, especially in the Prague archdiocese, shows that the episcopate was conscious of the emerging danger for priests and tried to respond to it (see the example of the vicar B.M. Kulda) $)^{29}$, albeit with a critical delay, a lack of thoroughness and, in the Moravian dioceses, even a certain laxness.

The crisis in priestly identity appeared in a latent, not yet acute form in pre-1848 times as a legacy of the Enlightenment, i.e. a response to the widening gap between the Enlightenment vision of the church as an ethical community and an Austrian variation on Catholicism from restoration times. However, the so far quite tentative expressions of modernism with which pre-1848 Austria was confronted did not seem to offer those uncertain priests beset by doubts the possibility of support and adequate networking in a circle of priests with similar opinions. Zátka's case in particular shows a response to this situation, to the urge to abandon a degree of solitude in the development of theological and ethical reflections, teaching activities and especially in the long-term planning of activities for the national emancipation movement. During this phase, this seems to have satisfied ideas about the acceptable level of dissociation from official church policy and from Austrian state Catholicism, and also about the degree of participation in public matters that was necessary and commensurate with the vocation. In any case, the conflicts of identity in the priestly profession in pre-1848 times cannot be considered as fully developed. Jan Zátka (1802-1881) and his rebellious contemporaries were more an inspiration to the following generation rather than truly being actors in the internal church struggle over the concept of modernism, although they naturally had a mass impact on the characterization of priestly identity.

Our set of personalities serves to illustrate developments in the priestly setting between the revolution of 1848 and the Concordat of 1855 on the one hand, and the end of the era of liberal governments in Cisleithania in 1879 on the other. These two significant milestones in Austrian and Czech history frame a key event in the universal history of the Catholic Church - the First Vatican Council. The dramatic fluctuations in Catholicism in this country in themselves led to a sharp delineation of the borders between self-confident priests and those rendered uncertain by developments in society and in the church, with the former quite naturally, in accordance with their previous upbringing, relying on the authority of Rome and the newly proclaimed dogma. The lack of consideration given to the risks associated with this rigid position, which

29 J. Halouzk a, Životopis Beneše Methoděje Kuldy, infulovaného sídelního kanovníka staroslavné královské kapituly vyšehradské, muže práce a oběti [A Biography of Beneš Methoděj Kulda, the Infulated Resident Canon of the Venerable Royal Chapter of Vyšehrad, a Man of Work and Sacrifice], Prague 1895; A. Ha velk a, Beně̌ Method Kulda, Prague 1903. 
set the church on a trajectory beset by numerous problems and dangerous controversies, was an understandable phenomenon given the situation at the time and the level of knowledge about the seriousness of the problem. There were, of course, attempts to seek refuge for strengthening self-esteem in discipline and unwavering obedience to Rome and the episcopate, as in the case of Antonín Lenz (1829-1901), and ignoring or downplaying sometimes excessively conservative attitudes that were incompatible with the reality of social problems and the expectations of those around them - or even, as the rather extreme example of Andreas Hamerle (1837-1930) shows, in a revival of spirituality and adherence to work methods that since Enlightenment times had seemed to be peripheral, outdated and on the decline..$^{30}$

In the two generations of priests which followed, the crisis of modernism was fully developed. Within the set we find all the aforementioned types of priestly identity and attitudes to problems associated with the priestly vocation. A very clearly characterized group is formed by priests deriving self-confidence and strength from an association with the authority of the papacy during a turbulent time as indicators of a trend which eliminated doubts and uncertainty very effectively. There are examples which show how this basic strategy could be adapted to meet the needs of a specific priest and his social environment. Although we still find a relatively limited spectrum of attitudes and identities among priests fully loyal to the official policies of Rome and the episcopate, the group of theology graduates from Rome particularly stand out here (e.g. František Zapletal). Among the growing number of priests maintaining their distance from these official authorities, we see a very varied portfolio, with individual groups identifying themselves through differences, through "the image of the enemy" (cf. the journalist Ambros Opitz). ${ }^{31}$ Not all strategies and types of identity are represented in the set under examination, but at the same time research into some individuals has already yielded plenty of inspirational literature which makes it possible to work effectively with their specific examples and life journeys in the analysis. The greatest breadth in terms of the variety of opinions and identities is offered by the modernist current in the church around the year 1900. ${ }^{32}$ This not only includes figures from Catholic modernity but also the traditionalistically, rurally oriented "modernists" whose best known representative is Jindřich Šimon Baar,

${ }^{30}$ F.W. B a utz, Andreas Hamerle, Biographisch-Bibliographisches Kirchenlexikon, Band II, 1990, Spalten 507-508, http://www.kirchenlexikon.de [access: 22 XII 2017]; A. P i c h le r, P. Andreas Hamerle, Ein Charakterbild,Warnsdorf 1934 pp. 9-13.

31 J. Gürtler, Ambros Opitz, Warnsdorf 1908. His role was particularly highly appraised, albeit only briefly by E. Winter, Tisíc let duchovního zápasu [The Thousand Year Religious Struggle], Prague 1940, pp. 276-277. Cf. also R. B a mberger, M. B a mberger, E. Bruckmüller, K. Gutkas (eds.), Oesterreich Lexikon II, Vienna 1995, p. 146. Here Opitz is called the leader of the Catholic Deutschböhmen, otherwise one of the few references is J.W. B o y e r, Political Radicalism in Late Imperial Vienna: Origins of the Christian Social Movement 1848-1897, Chicago-London 1981, p. 139, which describes him as a lone warrior. Also K. Ka is e rová, Konfesní myšlení českých Němců v 19. a na počátku 20. stoleti [The Religious Thought of Czech Germans in the $19^{\text {th }}$ Century and Start of the 20 $0^{\text {th }}$ Century], Úvaly u Prahy 2003, pp. 45-69.

32 P. Marek, Apologetové nebo kacíri? Studie a materiály $k$ dějinám české Katolické moderny [Apologists or Heretics? Studies and Materials on the History of Czech Catholic Modernism], Rosice u Brna 1999. 
the urban liberal priests who opposed him, and also politically active clergymen who played a role in the Christian-social movement, although even in this group individual representatives imposed these or other limits on themselves. A very specific position was occupied by the conservative Florian-Deml circle of priests and laymen.

From the set of individuals analysed, two can certainly be labelled as aspirants to a symbolic role, i.e. a sufficiently distinctive representation of a specific approach to the Church crisis of modernism to turn these individuals into generational symbols. Among other things, this meant that their work aroused and still arouses controversy. In the case of Jakub Deml, this concerns a strong link between priestly identity and artistic and literary activity; in the case of Bohumil Stašek, ${ }^{33}$ a link to political activity which was unusually strong for its time. In both cases, we are dealing with individuals who developed a specific response to the Church crisis of modernism within the Czech environment. With their closest followers and sympathizers, they represented that Mannheimian generational core within a generation of priests whose generational position offered a way out of the crisis. Eduard Winter sought other routes out of this crisis as a representative and spiritual leader of German (deutschböhmisch) Catholics in Bohemia. ${ }^{34}$

\section{CONCLUSION}

The research offered the possibility of an insight into questions concerning the identities facing priests, which have not yet received much attention from historical science, since this was not about strong supporters of any of the competing trends. Here we are particularly thinking of Emanuel Masák and Jan Pauly. Whereas with the former the restrained modernism of youth was transformed by the clash with the reality of society and the church into an inner (in middle age no longer publicly declared) conviction, with the latter a once problematic figure with opinions that were inconvenient to the episcopate became someone who made quite an

33 B. Sta šek, Když křžovali český národ [When the Czech Nation Was Crucified], Prague 1946; S. Vej var, Monsignore Bohumil Stašek - vưdči osobnost protišrámkovské opozice v ČSL [Monsignore Bohumil Stašek - a leading figure in the anti-Šramek opposition in the ČSL] [in:] Mar e k P. (ed.), Jan Šrámek. Kněz, státník, politik [Jan Šrámek. Priest, Statesman, Politician], Olomouc 2004, pp. 157-173; J. Kotous, M. Pehr (eds.), Bohumil Stašek (1886-1948) - Život a doba [The Life and Times of Bohumil Stašek (1886-1948)], Prague 2009; J. Š e bek, Jan Šrámek a Bohumil Stašek. Př́klady souladu $i$ disonance české a moravské katolické politiky po roce 1918 [Examples of Harmony and Dissonance in Bohemian and Moravian Catholic Politics after 1918], "Střed" 2010, no. 2, pp. 9-22.

${ }^{34}$ I. Lu ft, Religiöses Selbstverständnis und Kontinuitäten. Eduard Winter (1896-1982). Priester, Jugendführer, Theologe und Historiker (doctoral thesis at KTF Otto-Friedrich-Universität in Bamberg), Bamberg-Munich 2006, p. 1; J. Němec, Eduard Winter (1896-1982). Eine der bedeutendsten Persönlichkeiten der österreichischen Geistesgeschichte unseres Jahrhunderts ist in Österreich nahezu unbekannt [in:] K. Hruza (ed.), Österreichische Historiker 1900-1945. Lebensläufe und Karrieren in Österreich, Deutschland und der Tschechoslowakei in wissenschaftlichen Porträts, Vienna-CologneWeimar 2008, pp. 619-676. 
interesting career for himself within the church hierarchy following a change in political circumstances..$^{35}$

In terms of the development of the cognition of one's own role and position, it is equally important to reflect both the phase of a priest's adolescence, during which identity is formed from outside to a significant extent, and the next phase of life, characterized by an attempt to be true to his vocation or modify his own identity according to roles assigned by those around him, the authorities and the expectations of superiors, fellow brethren or parishioners. The modern, accelerating age generated more possibilities for individual choice, but also a greater number of lines of conflict.

Priestly identities in the Czech lands represent an attractive and fascinating topic, which cannot be summed up in a single sentence but can be reflected by at least five points of view: 1) securing one's position, 2) activities, 3) solitude, 4) Rome, 5) expectations from church authorities.

1) Priestly identity was formed primarily in the younger phase of working age. After attaining a permanent post or a secure position, the personality of the priest generally settled down.

2) However, securing a position did not lead to a reduction in the priests' pastoral work, the enumeration of their "evangelistic" activities and literary output.

3) The question of isolation was often more important than financial security. But in view of the growing administrative obligations and pastoral complications, the priest had few opportunities to live in a community or develop relationships with other priests. Because of this, associations, parties and congresses gained in importance.

4) In situations where Rome or the upper hierarchy called into question or banned these islands of collective consciousness, it was more difficult for the affected priests to find an affinity for the curia, unless they came up with a new strategy of their own.

5) The younger priests generally invested greater expectations in the bishop, especially in a new pastor who took an interest in the needs of the lower clergy. However, if the consistory was not able to help, feelings of frustration and injustice multiplied among priests (particularly older ones).

\section{BIBLIOGRAPHY}

B a mberger R., Bamberger M., Bruckmüller E., Gutkas K. (eds.), Oesterreich Lexikon II, Vienna 1995.

B a utz F.W., Andreas Hamerle, Biographisch-Bibliographisches Kirchenlexikon, Band II, 1990, Spalten 507-508, http://www.kirchenlexikon.de [access: 20.01. 2017].

${ }^{35}$ M.C. Putna, Česká katolická literatura v evropském kontextu 1848-1918 [Czech Catholic Literature in a European Context], Prague 1998, pp. 547-551; T. P a r m a, Francesco Zapletal, primo vicerettore del Bohemicum [in:] T. P a rma (ed.), Dal Bohemicum al Nepomuceno. La cultura ceca e la formazione sacerdotale in un contesto di scontri nazionalisti e di coesistenza, Olomouc 2011. 
B oy er J.W., Political Radicalism in Late Imperial Vienna: Origins of the Christian Social Movement 1848-1897, Chicago-London 1981.

Burleigh M., Pozemské mocnosti. Politická náboženstvi od Velké francouzské revoluce do 1. světové války [Earthly Powers. Political Religion form the Great French Revolution to the World War I], Prague 2016.

Corsten M., Čas generaci [The Time of a Generation], "Sociální studia" 2007, vol. 4, no. 1-2, pp. 46-65.

De 11 J., Zakázané světlo. Výbor z korespondence z let 1930-1939 [The Forbidden Light: A Selection of Correspondence from 1930-1939], Prague-Litomyšl 1999.

Fas ora L., Hanuš J., Malíř J. (eds.), Sekularizace českých zemí v letech 1848-1914 [The Secularization of the Czech Lands from 1848-1914], Brno 2007.

F a sora L., Hanuš J., Pavlíč ek T.W. (eds.), Kněžské identity v českých zemich (18201938) [Priestly Identity in the Czech Lands (1820-1938)], Prague 2016.

F ätk en h e u er F., Lebenswelt und Religion. Mikro-historische Untersuchungen an Beispiel aus Franken um 1600, Göttingen 2004.

Feeser-Lichterfeld U., Berufung. Eine praktisch-theologische Studie zur Revitalisierung einer pastoralen Grunddimension, Münster 2005.

F e rn er P., Hirte oder Herrscher? Die Identität des Priesters im Kontext der Diözese Innsbruck (doctoral thesis, Theological faculty, University of Innsbruck), Innsbruck 2009.

Fili pi P., Křest'anstvo. Historie, statistika, charakteristika krest’anských církvi [Christianity: The History, Statistics and Characteristics of Christian Churches], Brno 2012.

Fries 1 Ch. (ed.), Christen als Beruf. Chancen und Problemfelder theologische Karrieren, Innsbruck-Vienna 1996.

Frolcová V., František Sušil (1804-1868), odkaz a inspirace [František Sušil (18041868): Legacy and Inspiration], Rousínov 2004.

Gabriel K., Christentum zwischen Tradition und Postmoderne, Freiburg-Basel-Vienna 1992.

Gabriel KKa ufman n F.-X., Zur Soziologie des Katholizismus, Mainz 1980.

Gürtle r J., Ambros Opitz, Warnsdorf 1908.

Hah n H.H. (ed.), Stereotyp, Identität und Geschichte, Frankfurt 2002.

Hal as F.X., Fenomén Vatikán. Idea, dějiny a současnost papežství [The Vatican Phenomenon: The Ideas of the Papacy throughout History and Today], Brno 2004.

Halouzka J., Životopis Beněse Methoděje Kuldy, infulovaného sídelního kanovníka staroslavné královské kapituly vyšehradské, muže práce a oběti [A Biography of Beneš Methoděj Kulda, the Infulated Resident Canon of the Venerable Royal Chapter of Vyšehrad, a Man of Work and Sacrifice], Prague 1895.

Hanuš J. et al., "Služebníci neužitečni". Kněžské identita v českých zemích ve 20. století ["Useless Servants". Priestly Identity in the Czech Lands in the 20th Century], Brno 2015.

Hanu š J., Husák P., Kněžská identita ve 20. století [Priestly Identity in the $20^{\text {th }}$ century] [in:] Hanuš J. et al., "Služebnici neužitečni”. Kněžská identita v českých zemích ve 20. stoleti [ "Useless Servants". Priestly Identity in the Czech Lands in the $20^{\text {th }}$ Century], Brno 2015, pp. 5-48.

Havelk a A., Beneš Method Kulda, Prague 1903.

Havelka M., Ke dvěma intencím procesu sekularizace v 19. a 20. století [Towards Two Intentions of the Process of Secularization in the $19^{\text {th }}$ and $20^{\text {th }}$ Centuries], "Lidé města" 2009, 11/3, pp. 441-462.

Hro ch M., Hledání souvislostí. Eseje z komparativnich dějin Evropy [The Search for Connections: Essays in Comparative European History], Prague 2016. 
Jirou š ek T., Déjiny sociálního hnutí v zemích koruny české 1840-1909 [A History of the Socialist Movement in the Czech Crown Lands], vol. 1-3, Prague 1900-1909.

Kadlec J., Přehled cirkevnich českých dějin [An Overview of Czech Religious History], vol. 2, Rome 1987.

Ka is e rová K., Konfesni myšlení českých Němci̊ v 19. a na počátku 20. století [The Religious Thought of Czech Germans in the $19^{\text {th }}$ Century and Start of the 20 $0^{\text {th }}$ Century], Úvaly u Prahy 2003.

Kerkhofs J., Zulehner P.M., Europa ohne Priester? Düsseldorf 1995.

Kotous J., Pehr M. (eds.), Bohumil Stašek (1886-1948) - Život a doba [The Life and Times of Bohumil Stašek (1886-1948)], Prague 2009.

Küng H., Unfehlbar? Eine Anfrage, Zürich-Einsiedeln-Cologne 1970.

Luft I., Religiöses Selbstverständnis und Kontinuitäten. Eduard Winter (1896-1982). Priester, Jugendführer, Theologe und Historiker (doctoral thesis at KTF Otto-Friedrich-Universität in Bamberg), Bamberg-Munich 2006.

Malý T., Spása a smrt mezi Tridentinem a sekularizací. Brněnští měštané a proměny laické zbožnosti v 17. a 18. století [Salvation and Death Between the Tridentine and Secularization. The Brno Bourgeoisie and Changes in Lay Piety in the $17^{\text {th }}$ and $18^{\text {th }}$ Centuries], Brno 2009.

Ma rek P., Apologetové nebo kaciríi? Studie a materiály k dějinám české Katolické moderny [Apologists or Heretics? Studies and Materials on the History of Czech Catholic Modernism], Rosice u Brna 1999.

Marek P., Identita kněžské generace 20. let 20. století [Priestly Generation Identity of Generation of the twenties of the $20^{\text {th }}$ century], "Církevní dějiny" 2014, Roč. 7, č. 15, pp. 9-30.

Něm e c J., Eduard Winter (1896-1982). Eine der bedeutendsten Persönlichkeiten der österreichischen Geistesgeschichte unseres Jahrhunderts ist in Österreich nahezu unbekannt [in:] Hruza K. (ed.), Österreichische Historiker 1900-1945. Lebensläufe und Karrieren in Österreich, Deutschland und der Tschechoslowakei in wissenschaftichen Porträts, Vienna-Cologne-Weimar 2008, pp. 619-676.

$\mathrm{N}$ e š p or Z.R., Náboženství na prahu nové doby. Česká lidová zbožnost 18. a 19. století [Religion on the Threshold of a New Age. Popular Czech Piety in the $18^{\text {th }}$ and $19^{\text {th }}$ Century], Ústí nad Labem 2006.

N e š p or Z.R., Náboženství v 19. století. Nejcirkevnější století, nebo období zrodu českého ateismu? [Religion in the 19 $9^{\text {th }}$ Century: The Most Religious Century or the Period of the Birth of Czech Atheism?], Prague 2010.

Oli č J., Čtení o Jakubu Demlovi [Readings on Jakub Deml], Olomouc 1997.

P arm a T., Francesco Zapletal (1861-1935), primo vicerettore del Bohemicum [in:] T. P a rma (ed.), Dal Bohemicum al Nepomuceno. La cultura ceca e la formazione sacerdotale in un contesto di scontri nazionalisti e di coesistenza, Olomouc 2011.

Pavlíček T.W., Katholizismus in der Moderne. Religiöser Wandel und die Positionierung des Klerus in Böhmen und Bayern in der zweiten Hälfte des 19. Jahrhunderts [in:] M. Hlavačk a, R. Lu ft, U. L u now (eds.), Tschechien und Bayern. Gegenüberstelungen und Vergleiche vom Mittelalter bis zur Gegenwart, München 2016, pp. 169-184.

Pi chler A., P. Andreas Hamerle, Ein Charakterbild, Warnsdorf 1934.

Pirklbauer B., Christen als Beruf. Neue Perspektiven für theologische Karrieren, Innsbruck-Vienna 1996.

P irklb a u e r B., Priesteridentität zwischen Kirche und Gesellschaft, Linz 1998. 
Pottme y e r H.J., Unfehlbarkeit und Souveränität. Die päpstliche Unfehlbarkeit im System der ultramontanen Eklesiologie des 19. Jahrhunderts, Mainz 1975.

P ow er M., Kuč er a R., Úvod: kategorie identity v současné historiografii [Introduction: The Category of Identity in Contemporary Historiography] [in:] R. K u č e r a et al., Identity v českých zemích 19. a 20. století: Hledáni a promény [Identities in the Czech Lands in the $19^{\text {th }}$ and $20^{\text {th }}$ Centuries: Searches and Transformations], Prague 2012, pp. 9-23.

P u tn a M.C., Česká katolická literatura v evropském kontextu 1848-1918 [Czech Catholic Literature in a European Context 1848-1918], Prague 1998.

Řezníková L., Identita/alterita [in:] L. S torchová et al., Koncepty a dějiny. Proměny pojmů v současné historické védě [Concepts and History. Conceptual Changes in Contemporary Historical Science], Dolní Břežany 2014, pp. 233-243.

Ri e s enbrodt M., Cultus und Heilsversprechen, Munich 2007.

S a pi en za L., Muž Boží. Stránky o kněžské spiritualitě [Man of God. Writings on Priestly Spirituality], Olomouc 2009.

Schmidtchen G., Priester in Deutschland. Forschungsbericht über d. im Auftrag der Deutschen Bischofskonferenz durcheführte Umfrage unter allen Welt- u. Ordenpriester in d. Bundesrepublik Deutschland, Freiburg-Basel-Vienna 1973.

Schreuder O., Der alarmierende Trend. Ergebnisse einer Umfrage im gesamten holländischen Klerus, Munich 1969-1970.

Stašek B., Když křžovali český národ [When the Czech Nation Was Crucified], Prague 1946.

Š e bek J., Jan Šrámek a Bohumil Stašek. Př́klady souladu i disonance české a moravské katolické politiky po roce 1918 [Examples of Harmony and Dissonance in Bohemian and Moravian Catholic Politics after 1918], "Střed” 2010, no. 2, pp. 9-22.

Ším a J., K sociologii duchovniho [Towards a Sociology of the Clergy], Praha 1937.

Š o tola J., Kariéra v černém. Předpoklady pro získání beneficia v 18. století [A Career in Black. Requirements for Obtaining a Benefice in the $18^{\text {th }}$ Century], "Časopis Matice moravské" 2007, vol. 126, no. 2, pp. 319-341.

Vejvar S., Monsignore Bohumil Stašek - vưdči osobnost protišrámkovské opozice v ČSL [Monsignore Bohumil Stašek - a leading figure in the anti-Šramek opposition in the ČSL] [in:] P. Mar e k (ed.), Jan Šrámek. Kněz, státník, politik [Jan Šrámek. Priest, Statesman, Politician], Olomouc 2004, pp. 157-73.

Victor Ch., Pfarrer sein in wechselnden Gesellschaften. Eine Quantitative Untersuchung zu Identität und Alltag im Pfarrberuf, Leipzig 2005.

Winter E., Tisic let duchovniho zápasu [The Thousand Year Religious Struggle], Prague 1940 .

Zulehner P.M., Kirche und Priester zwischen den Aufratg Jesu und der Erwartungen der Menschen, Linz 1974.

Zu lehn e r P.M., Priester im Modernisierungsstress, Ostfildern 2001. 